\title{
ANALISIS PENDAPATAN PETANI CENGKEH BERDASARKAN SKEMA USAHATANI DI KABUPATEN BOLAANG MONGONDOW TIMUR
}

\author{
Diaz Giffari Dilapanga $\left.{ }^{\star}\right) 1$, Asda Rauf ${ }^{2)}$, Yuriko Boekoesoe ${ }^{2)}$ \\ 1) Jurusan Agribisnis Fakultas Pertanian Universitas Negeri Gorontalo \\ 2) Fakultas Petanian Universitas Negeri Gorontalo \\ $\left.{ }^{*}\right)$ E-mail Penulis Korespondensi: diazdilapanga97@gmail.com
}

\begin{abstract}
ABSTRAK
Tujuan penelitian ini adalah untuk menganalisis pendapatan petani cengkeh berdasarkan skema usahatani serta membandingkan kedua skema usahatani petani cengkeh di Desa Molobog Kecamatan Motongkad Kabupaten Bolaang Mongondow Timur. Jenis data yang digunakan data primer dan data sekunder. Sampel diambil dengan teknik purposive sampling dengan penentuan jumlah sampel menggunakan metode Slovin sehingga diperoleh sampel sebanyak 56 orang. Tehnik analisis data menggunakan analisis deskriptif kuantitatif. Data dianalisis dengan pendekatan matematis yaitu perhitungan pendapatan. Hasil penelitian menunjukan bahwa kedua skema usahatani cengkeh yang berkembang yaitu petani pemilik pengelola dan petani pemilik yang menyewakan. Pendapatan dari kedua skema usahatani cengkeh petani yang mengelola dan petani yang menyewakan yaitu rata-rata pendapatan petani pemilik pengelola sebesar Rp. 31.857 .464 dan rata-rata petani pemilik yang menyewakan sebesar Rp. 11.848.485. Dari hasil ini, petani pemilik yang mengelola usahatani cengkeh lebih menguntungkan dibandingkan petani yang menyewakan usahatani cengkehnya.
\end{abstract}

Kata Kunci: skema usahatani; pendapatan petani; Cengkeh

\section{PENDAHULUAN}

Cengkeh sebagai salah satu komoditas hasil pertanian yang diharapkan dapat membantu meningkatkan pendapatan dan kesejahteraan petani (Mahreni, 2010). Kondisi cengkeh di tingkat nasional mengalami pasang surut mengingat fluktuasi harga cengkeh yang cukup besar dan biaya panen dan pengolahan cukup tinggi, sementara itu di sisi teknis tanaman cengkeh mempunyai karakteristik yang khas yaitu adanya panen besar diikuti panen kecil pada tahun berikutnya serta panen raya pada periode tertentu.Panen besar atau panen raya harga cenderung menurun yang mengakibatkan petani merugi dan kemudian tidak memelihara tanamannya.Hal tersebut mengakibatkan pertanaman kurangbaik dan produksi rendah (Siregar, 2011:). Komoditas cengkeh sangat berperan dalam perekonomian nasional yang memberikan kontribusi terhadap pendapatan Negara berupa cukai dan pajak sebesar 30 triliun rupiah pertahun (Kemala, 2004)

Provinsi Sulawesi Utara merupakan salah satu Wilayah penghasil komoditi cengkeh yang terletak di ujung pulau Sulawesi dimana Provinsi Sulawesi Utara memiliki beberapa Kabupaten penghasil cengkeh. Luas perkebunan tanaman cengkeh di Sulawesi Utara yaitu 74.932,01 Ha.. Berdasarkan BPS 2017, Kabupaten Bolaang Mongondow Timur adalah bagian dari Provinsi Sulawesi Utara yang memiliki luas wilayah $910,18 \mathrm{~km}^{2}$. Luas lahan tanaman cengkeh di Kabupaten Bolaang Mongondow Timur 4.342,06 Ha.. Kabupaten Bolaang Mongondow Timur memiliki 3 tanaman yang menjadi unggulan yaitu kelapa, cengkeh dan pala. 
Kecamatan Motongkad adalah bagian dari Bolaang Mongondow Timur yang baru memisahkan menjadi kecamatan. Desa Molobog yang terletak di Kecamatan Motongkad Kabupaten Bolaang Mongondow Timur yang sebagian besar masyarakatnya sebagai petani cengkeh, ini dapat dilihat dari luas dari Desa Molobog yaitu $24.749,5 \mathrm{~km}^{2}$ luas lahan yang diperuntukkan untuk pemukiman adalah $35 \%\left(8.662,5 \mathrm{~km}^{2}\right)$, untuk pertanian $45 \%$ $\left(11.137 \mathrm{~km}^{2}\right)$ dan untuk laut $20 \%\left(4.950 \mathrm{~km}^{2}\right)$.

Masyarakat Desa Molobog yang kebanyakan sebagai petani yang secara umum Desa Molobog mempunyai ciri Geologis berupa tanah warna cokelat, tekstur tanah yang gembur dan padat sehingga cocok sebagai lahan pertanian dan perkebunan sehingga masyarakat dapat memanfaatkan kondisi tersebut dengan menanam tanaman yang cocok di budidayakan di Desa Molobog. Hal ini memungkinkan cocok untuk tanaman-tanaman musiman dan tahunan berupa kelapa, jagung, coklat dan cengkeh.

Cengkeh banyak dibudidayakan oleh petani di desa molobong karena tanaman tersebut dapat menambah pendapatan mereka. Petani cengkeh disana mulai panen cengkeh ditengah anjloknya harga kisaran Rp.60.000 per/kg.Para petani khawatir tidak bisa memperoleh keuntungan maksimal karena modal besar tidak sebanding dengan harga jual yang rendah. Adapun tujuan penelitian ini untuk menganalisis pendapatan petani cengkeh berdasarkan skema usahatani yang tumbuh dan berkembang, serta membandingkan kedua skema usahatani manakah yang lebih menguntungkan untuk petani cengkeh di Desa Molobog, Kecamatan Motongkad, Kabupaten Bolaang Mongondow Timur.

\section{METODE}

Jenis penelitian ini merupakan jenis penelitian kuantitatif yang menggunakan data yang bersumber langsung dari petani berupa pendapatan petani cengkeh. Penelitian ini dilakukan di Desa Molobog, Kecamatan Motongkad, Kabupaten Bolaang Mongondow Timur, Provinsi Sulawesi Utara dan Penelitian ini dilakukan selama dua bulan dari bulan Maret sampai dengan bulan April tahun 2019.

Tehnik pengambilan sampel yang digunakan adalah tehnik purposive sampling dan diperoleh 128 petani cengkeh di Desa Molobog Kecamatan Motongkad Kabupaten Bolaang Mongondow Timur. Penentuan jumlah sampel yang akan digunakan menggunakan metode Slovin dengan rumus sebagai berikut :

$$
n=\frac{N}{1+N(e)^{2}}
$$

Dimana :

$\begin{array}{ll}\mathrm{n} & \text { : Ukuran sampel } \\ \mathrm{N} & \text { : Jumlah populasi } \\ \mathrm{e} & \text { : nilai presisi }\end{array}$

Dari hasil perhitungan, dengan menggunakan tingkat kepercayaan $90 \%$, atau tingkat kesalahan (10\%), maka diperoleh jumlah sampel sebanyak 56 orang petani, dengan perhitungan sebagai berikut:

$$
\frac{128}{1+128(0,10)^{2}}=\frac{128}{1+128(0,10)^{2}}=\frac{128}{1+1,28}=\frac{128}{2,28}=56 \text { orang }
$$

Tehnik analisis data yang digunakan dalam penelitian ini adalah analisis deskriptif kuantitatif. Data dianalisis dengan pendekatan matematis yaitu perhitungan pendapatan petani cengkeh, dirumuskan sebagai berikut : 


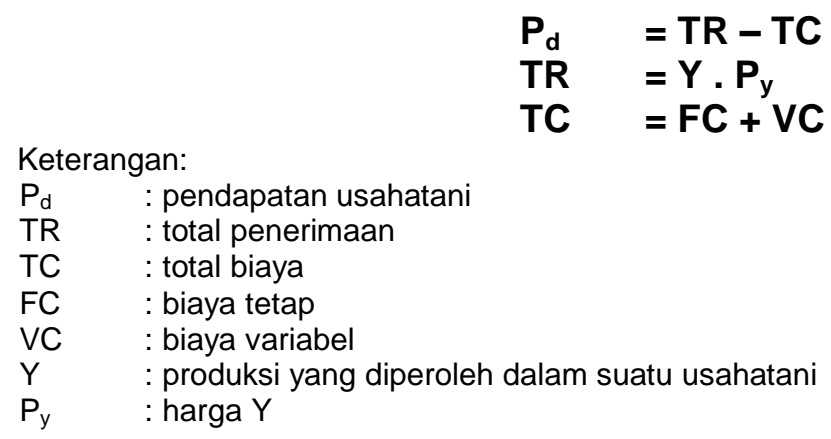

\section{HASIL DAN PEMBAHASAN}

\section{Skema Usahatani}

Tanaman cengkeh tanaman asli Indonesia yang berasal dari kepulauan Maluku (Randriani dan Syafaruddin, 2011).Tanaman cengkeh merupakan salah satu komoditas pendapatan potensial masyakat Indonesia khususnya Indonesia Timur karena sebagian besar digunakan sebagai bahan baku rokok kretek khas Indonesia dan sebagian kecil sebagai bahan campuran makanan, obat-obatan dan komestik (Marasabessy, 2015). Tanaman Cengkeh yang ditemukan di kawasan timur Indonesia.Tanaman ini termasuk dalam famili myrtaceae yang ditemukan di dataran rendah dengan ketinggian 200-900 m di atas permukaan laut. Tinggi dari tanaman cengkeh dapat mencapai 5-10 m (Rorong, 2008). Di Desa Molobog Kecamatan Motongkad Kabupaten Bolaang Mongondow Timur salah satu desa yang sebagian besar mata pencahariannya sebagai petani. Di Desa Molobog terdapat skema usahatani yang berkembang bukan hanya pada tanaman cengkeh namun pada tanaman pertanian lainnya yaitu skema usahatani petani pemilik pengelola dan petani pemilik yang menyewakan panen dari tanaman cengkeh.

Petani Pemilik pada umumnya adalah para petani Pemilik yakni yang mengelola panen dari tanaman cengkeh di Molobog, mengelola usahatani cengkeh di Molobog tidak memerlukan biaya yang banyak karena tanaman cengkeh dapat tumbuh dengan baik disana tanpa menggunakan pupuk dan obat-obatan dari tanaman cengkeh. Tanaman cengkeh juga tidak memerlukan perawatan yang lebih, cukup lahan yang bersih dan tanaman disiram dan terkadang tidak perlu menyiraminya karena penanaman cengkeh oleh para petani pada musim hujan. Tanaman cengkeh dengan biaya yang relatif kurang dan pendapatan yang cukup besar sangat bagus dibudidayakan di Desa Molobog. Cengkeh juga tanaman yang banyak dibudidayakan di Kabupaten Bolaang Mongondow Timur.

Petani pemilik yang menyewakan cengkeh yang merupakan tanaman unggulan di Kabupaten Bolaang Mongondow Timur karena hasil melimpah dengan biaya yang sedikit. Karena hasil yang melimpah banyak investor yang menginvestasikan hartanya untuk menyewa tanaman cengkeh guna mendapatkan keuntungan yang lebih. Menyewakan panen tanaman cengkeh sudah menjadi hal yang biasa di tengah masyarakat Desa Molobog karena para petani tanaman cengkeh menyewakan tanaman cengkeh guna memenuhi kebutuhan hidup sehari-hari. Proses menyewakan panen tanaman cengkeh para petani di Desa Molobog yaitu dengan menyewakan per panennya dengan harga yang disepakati jika mengalami gagal panen maka penyewa bisa menunda ke panen berikutnya.

\section{Pendapatan Petani Pemilik Pengelola Usahatani Cengkeh Biaya Tetap dan Biaya variabel}

Biaya usahatani merupakan seluruh biaya yang dikeluarkan petani seperti biaya tetap maupun biaya variabel. Adapun total seluruh biaya usahatani petani responden di Desa Molobog Kecamatan Motongkad Kabupaten Bolaang Mongondow Timur, ditunjukkan 
pada Tabel 1. Biaya tetap merupakan biaya yang penggunaannya tidak habis dalam satu masa produksi. Biaya tetap dalam usahatani cengkeh ini meliputi pajak lahan, penyusutan alat (cangkul, hand sprayer, dan mesin potong rumput), sedangkan biaya variabel usahatani cengkeh yaitu biaya obat-obatan (Basmilang dan Noxone) dan sewa tenaga kerja. Adapun biaya tetap dan biaya variabel usahatani cengkeh di Desa Molobog Kecamatan Motongkad Kabupaten Bolaang Mongondow Timur adalah sebagai berikut :

Tabel 1. Total Biaya Usahatani Cengkeh

\begin{tabular}{lrrr}
\hline \multicolumn{1}{c}{ Jenis biaya } & Jumlah biaya & Rata-rata biaya & \multicolumn{1}{c}{$\%$} \\
\hline Biaya Tetap : & & & \\
- Pajak Lahan & 3.068 .000 & 54.786 & 48,75 \\
- Penyusutan & 3.225 .000 & 57.589 & 51,25 \\
Total biaya tetap & 6.293 .000 & 112.375 & 100,00 \\
\hline Biaya variabel : & & & \\
- Obat-obatan & 5.415 .000 & 96.696 & 1,08 \\
- Sewa tenaga kerja & 494.150 .000 & 8.824 .107 & 98,92 \\
Total biaya variabel & 499.565 .000 & 8.920 .804 & 100,00 \\
\hline Total Biaya & $\mathbf{5 0 5 . 8 5 8 . 0 0 0}$ & $\mathbf{9 . 0 3 3 . 1 7 9}$ & \\
\hline
\end{tabular}

Sumber: Data diolah, 2019

Tabel 1 menunjukkan bahwa total biaya usahatani cengkeh di desa Molobog kecamatan Motongkad kabupaten Bolaang Mongondow Timur terdiri dari biaya tetap dan biaya variabel dengan rata-rata sebesar Rp.9.033.179. Adapun biaya tetap pada usahatani cengkeh diperoleh dari biaya pajak lahan yang dibayarkan petani pemilik lahan dan biaya penyusutan yang digunakan dalam penggunaan alat selama proses penanaman sampai panen, dimana alat yang digunakan adalah hand sprayer dan mesin pangkas.

Untuk biaya variabel yang digunakan dilihat lebih tinggi dibanding dengan biaya tetap. Biaya variabel diperoleh dari biaya penggunaan obat-obatan dan sewa tenaga kerja. Presentase biaya penggunaan obat-obatan dapat dikatakan sangat rendah dibanding biaya sewa tenaga kerja. Tenaga kerja usahatani cengkeh berasal dari luar keluarga. Tenaga kerja dari luar keluarga melakukan pekerjaannya yaitu pemeliharaan, pemetikan serta pengangkutan, dimana pembiayaan terbesarnya yaitu pada biaya pemetikan dan pengangkutan.

\section{Penerimaan dan Pendapatan Usahatani Cengkeh}

Penerimaan usahatani merupakan hasil perkalian antara hasil produksi dengan harga jual yang berlaku pada tingkat petani, sedangkan pendapatan diperoleh dari selisih antara penerimaan dengan total biaya usahatani cengkeh. Adapun penerimaan dan pendapatan usahatani cengkeh yang diperoleh petani di Desa Molobog Kecamatan Motongkad Kabupaten Bolaang Mongondow adalah pada Tabel 2.

Tabel 2 menunjukkan penerimaan usahatani cengkeh yang diperoleh dari jumlah produksi tanaman cengkeh selama produksi dengan harga jual cengkeh. Total penerimaan yang diperoleh setiap petani sebesar Rp.40.885.714/kg. Untuk pendapatan diperoleh dari selisih penerimaan dengan total biaya yang dikeluarkan selama proses produksi. Pendapatan petani berdasarkan nilai rata-rata petani yaitu Rp. 31.857.464. 
Tabel 2. Penerimaan dan Pendapatan Usahatani Cengkeh

\begin{tabular}{lrrr}
\hline \multicolumn{1}{c}{ Uraian } & Jumlah biaya & $\begin{array}{c}\text { Rata-rata per } \\
\text { petani (Rp/kg) }\end{array}$ & \multicolumn{1}{c}{$\%$} \\
\hline Penerimaan : & 25.440 & & \\
- Produksi (kg) & 90.000 & 454 & - \\
- Harga (Rp) & 2.289 .600 .000 & - & - \\
Total penerimaan & 505.858 .000 & 40.885 .714 & 81,91 \\
Total biaya & $\mathbf{1 . 8 4 . 0 1 8 . 0 0 0}$ & $\mathbf{3 1 . 8 5 7 . 2 7 9}$ & 18,09 \\
\hline Total pendapatan & \multicolumn{1000}{c}{} \\
\hline \multicolumn{2}{l}{ Sumber: Data diolah, 2019}
\end{tabular}

\section{Pendapatan Petani Pemilik yang Menyewakan Usahatani Cengkeh}

Pendapatan petani pemilik yang menyewakan usahatani cengkeh merupakan salah satu alternatif petani responden untuk memenuhi kebutuhan lebih awal dibandingkan menunggu hasil dari tanaman cengkeh jika tanaman cengkeh berbuah dan dijual. Kegiatan menyewakan usahatani cengkeh petani responden di Desa Molobog Kecamatan Motongkad Kabupaten Bolaang Mongondow Timur sudah menjadi hal yang biasa di tengah masyarakat untuk memenuhi kebutuhan para petani.

Tabel 3. Pendapatan Petani Pemilik yang Menyewakan

\begin{tabular}{lccr}
\hline Pendapatan sewa & $\begin{array}{c}\text { Harga sewa } \\
\text { (Rp) }\end{array}$ & $\begin{array}{c}\text { Lama menyewakan } \\
\text { (musim/tahun) }\end{array}$ & Total pendapatan \\
\hline Jumlah & 158.500 .000 & 16 & 130.333 .333 \\
Rata-rata & 14.409 .091 & 1 & 11.848 .485 \\
\hline
\end{tabular}

Sumber: Data diolah, 2019

Berdasarkan Tabel 3, petani pemilik menyewakan lahan cengkeh kepada petani dimana hasil yang didapat dari menyewakan tanaman cengkeh permusimnya yaitu sebesar Rp 130.333.333 dengan total rata-rata sebesar Rp 11.848.485 selama 1 musim tanam.

\section{Perbandingan Pendapatan Petani Yang Mengelola dan Petani Yang Menyewakan}

Pendapatan petani di Desa Molobog Kecamatan Motongkad Kabupaten Bolaang Mongondow Timur dapat dibedakan menjadi dua yaitu petani yang mengelola dan petani yang menyewakan panen tanaman cengkeh. Kebiasaan petani dengan kedua skema tersebut sudah berlangsung lama, petani yang mengelola hasil penen tanaman cengkeh umumnya karena pada musim itu hasil panen melimpah dan orang yang menawarkan untuk menyewa tidak mendapati kesepakatan. Petani yang menyewakan kebanyakan dari petani yang terdesak untuk memnuhi kebutuhan keluarga. Perbandingan skema usahatani jika ditinjau dari sisi pendapatan yaitu antara petani pemilik pengelola dan petani pemilik yang menyewakan usahatani cengkeh di Desa Molobog Kecamatan Motongkad Kabupaten Bolaang Mongondow Timur ditunjukkan pada Tabel 4.

Tabel 4. Pendapatan Petani Pemilik Pengelola dan Pendapatan Petani yang Menyewakan

\begin{tabular}{lccr}
\hline Skema usahatani & $\begin{array}{c}\text { Harga sewa } \\
\text { (Rp) }\end{array}$ & $\begin{array}{c}\text { Lama menyewakan } \\
\text { (musim/tahun) }\end{array}$ & Total pendapatan \\
\hline $\begin{array}{l}\text { Petani yang } \\
\text { mengelola }\end{array}$ & 1.784 .018 .000 & 31.857 .464 & 72,89 \\
$\begin{array}{l}\text { Petani yang } \\
\text { menyewakan }\end{array}$ & 130.333 .333 & 11.848 .485 & 27,11 \\
\hline
\end{tabular}


Tabel 4 menunjukkan bahwa hasil pendapatan terbesar yaitu pada petani yang mengelola dengan besaran presentase $72,89 \%$, dimana selisihnya $46,78 \%$ dibanding hasil pendapataan dari petani yang menyewakan tanaman cengkeh per musimnya. Dari hasil tersebut dapat dikatakan bahwa pendapatan petani yang mengelola usahatani cengkehnya jauh lebih menguntungkan dibanding petani yang menyewakan usahatani cengkehnya, namun disisi lain dalam tujuan untuk memenuhi kebutuhan keluarga, sehingga hal tersebut sudah menjadi kebiasaan petani di desa Molobog Kecamatan Motongkad Kabupaten Bolaang Mongondow Timur untuk menyewakan usahatani cengkehnya.

\section{SIMPULAN}

Pendapatan petani cengkeh yang mengelola sendiri rata-rata petani sebesar Rp 31.857.464/musim dan petani yang menyewakan rata-rata pendapatan petani sebesar $\mathrm{Rp}$ 11.848.485/musimnya. Petani yang mengelola sendiri lebih besar pendapatannya daripada petani yang menyewakan di karenakan petani yang mengelola sendiri tanaman cengkeh tidak memerlukan biaya yang begitu besar yaitu rata-rata sebesar Rp 9.028.250 dengan penerimaan rata-rata $\mathrm{Rp} 40.885 .714$ sedangkan petani yang menyewakan tanamannya rata-rata harga sewa sebesar $\mathrm{Rp} 14.409 .091$ ini dikarenakan petani yang menyewakan memilih cara yang praktis untuk mendapatkan uang atau untuk memenuhi kebutuhan hidup.

\section{DAFTAR PUSTAKA}

Badan Pusat Statistik Provinsi Sulawesi Utara. 2017. Provinsi Sulawesi Utara dalam Angka. Sulawesi Utara.

Kemala, S. 2004. Status Tanaman, Produksi Dan Penggunaan Cengkeh. Jurnal.Balai Penelitian Tanaman Rempah dan Obat. Jurnal Penelitian Tanaman Industri, Vol. 10, No. 4, HIm. 59-65

Mahreni. 2010. Peluang dan Tantangan Komersialisasi Biodiesel-Review. Jurnal. Eksergi, Vol. 10, No. 2, HIm. 15-26

Marasabessy, Dessy A. 2015. Kearifan Lokak Pengelolaan Budidaya Cengkeh (Syzygium aromaticum) di Kecamatan Leihitu Barat Dan Kecamatan Salahutu Kabupaten Maluku Tengah. Jurnal Makila, Vol. 9, No. 1, HIm. 124-132

Randriani, E. dan Syafaruddin. 2011. Keragaan Pohon Cengkeh Terpilih Tipe Zanzibar dan Siputih Palabuhanratu. Buletin RISTRI, Vol., 2, No.3, HIm. 405-410

Rorong, J. 2008. Uji Aktivitas Antioksidan Dari Daun Cengkeh (Eugenia Carryophyllus) Dengan Metode DPPH. Jurnal.Chem. Prog., Vol. 1 No. 2, HIm. 111-116

Siregar, A.R. 2011. Analisis Disparitas Harga dan Potensi Persaingan Tidak Sehat Pada Distribusi Cengkeh. Jurnal Agribisnis, Vol. 10, No. 3, HIm. 32-34. 